Environment, Biodiversity \& Soil Security
(EBSS)

\title{
Potential Impacts of Copper Sulfate and Sodium Silicate Salts of Maize Late Wilt Disease and Synthase of Anti-defense Compounds
}

Gamal A. Farahat

Agricultural Research Center, Plant Pathology Research Institute, Sakha Research Station, Kafr El-Sheikh 33717, Egypt.

\begin{abstract}
M AIZE seeds coating by copper sulfate and sodium silicate salts exhibited non phytotoxic and led to reduce late wilt disease infection percentage under field conditions during tested seasons compared to control treatment. A fertilizer by $5-25 \mathrm{~g} \mathrm{plot}^{-1}$ of these salts added at first and second irrigations separately to maize seedlings led to retarding of late wilt disease in the field and caused reduction of infection percentage with the most salts tested concentrations. Reduction of the disease as salts application resulted in enhancement of yield especially with high concentrations. Increasing of salt concentrations led to increase the retarding of late wilt disease and reduction of infection percentage. Generally, copper sulfate was more effective against late wilt disease than sodium silicate and recorded high retarding of disease and the highest enhancement of the yield in comparison of control and other treatments. Induction of peroxidase and polyphenol oxidase enzymes synthase by salts application may be have role in retarding late wilt disease as well as increasing of chemical compounds of fat, ash and carbohydrates content. The reverse was true in case of antioxidant and total phenols, which extracts of treatments possessed activity in all with non-significant with control treatment.
\end{abstract}

Keywords: Copper sulfate, Sodium silicate, Maize, Late wilt, Oxidative enzymes, Phenols and antioxidant.

\section{Introduction}

Maize (Zea mays L.) is a cereal crop grown throughout the world and plays an important role in the diet of millions of African people due to its high yields per hectare (Asawalan 2006). In Egypt, maize is the third important grain crop after wheat and rice for human consumption, as well as for animal feeding.

Late wilt is a vascular wilt disease of maize that caused by soil born and seed born fungus of Harpophora maydis (Samra et al., 1966) W. Gams with syn.: Cephalosporium maydis (CABI, 1999; El-Shafey and Claflin, 1999). Late wilt was first reported of maize in Egypt in 1960 and considered the most economically important fungal disease, serious economic losses up to $40 \%$ of grain yield and $100 \%$ infection disease affected $70 \%$ of plants occurs in susceptible varieties (Labib et al., 1975 and Johal et al., 2004).

The mineral nutrition for plant growth and vigor is obvious. The role of nutrients in plant disease resistance and root stress tolerance is less well known but is gaining increase attention and addition of micronutrients to plant crop results in decrease in the incidence of many diseases. These nutrients are required for polyphenol formations and phenolic metabolism and hence they are crucial for plant defense capability (Huber and Withelm, 1988 and Graham and Webb, 1991). Copper (Cu) based antimicrobial with high toxicity to plant pathogens, low costs, low mammalian toxicity of the fixed compounds and their chemical stability (Lamichhane et al., 2018). In addition to direct application on plants in the field, it used for seed treatment to prevent infection by plant pathogens

Corresponding author : gamalf8@gmail.com

Received : 18 / 12 / 2019 ; Accepted: 8 / 3 / 2020

DOI: $10.21608 /$ jenvbs.2020.21138.1079

C)2019 National Information and Documentation Center (NIDOC) 
(Verma et al., 2011). A number of inorganic $\mathrm{Cu}$ formulations $\left(\mathrm{SO}_{4}\right)$ used as biocide to control plant pathogenic fungi, bacteria, etc. (Capinera and Dickens, 2016). Singh and Siradhana (1990) showed that micronutrients of $\mathrm{Cu}, \mathrm{Fe}, \mathrm{Mn}$ and $\mathrm{Zn}$ were reduced late wilt disease incidence. Cupric sulfate was the most effective one in retarding of powdery mildew disease under field conditions in sugar beet (Eliwa et al., 2018 and Farahat \& Salama, 2019) and elevated of peroxidase and glucanase activity in cucumber plants (Reuveni et al., 1997). Farahat et al. (2011) and El-moghazy et al. (2011) reported that, sulfates of $\mathrm{Cu}$ was significantly reduced the growth and effective in retarding of the fungus of $C$. beticola fungus in vitro, and the best one of significant reduction of cercospora field disease severity. Precigout et al. (2017) stated that, diminishing the use of fertilizers could reduce biotrophic fungal epidemics.

Silicon ( $\mathrm{Si}$ ) fertilization of soil has been shown to significantly retard many diseases susceptibility i.e. neck blast, brown spot (Datnoff et al., 1991), crown and root rot of Pythium (Cherif et al., 1994), Fusarium wilt (Belanger et al., 1995), root mortality, root decay by stimulating host plant defenses (Cherif and Belanger, 1992), accumulation of phenols which seriously damage of fungal hyphae penetrating the phenolic-laden amended plants and conclusively showed to be fungi toxic (Cherif et al., 1994) and increased yield considerably in response to Si fertilization (Winslow, 1992). Si reduces the severity of important diseases such as blast and sheath blight of rice, powdery mildew of wheat, barley, cucumber and tomato, ring spot in sugarcane, rust of cowpea, gray leaf spot of ryegrass and back sigatoka of banana (Datnoff et al., 2007; Nanayakkara et al., 2008 a,b; Rezende et al., 2009 and Kablan et al., 2012) and this improves yield and quality (Datnoff et al., 2001). Also, several favorable effects due to proper $\mathrm{Si}$ nutrition on growth, development and health status of plants including increasing of growth (height), production and exposure of leaves to light (photosynthesis), earlier soil and soilless Si (sodium and calcium silicate) application to enhance disease control (Datnoff et al., 2007). Datnoff et al. (2012) showed that, Si suppress a number of root diseases under greenhouse and field conditions especially soils and soilless mixes , also those caused by fungal like (Oomyceta), bacteria, virus and nematodes by responses of plant at the biochemical and molecular levels .Moreover, Liang et al. (2005) and Guevel et al.
(2007) found that, Si root applied was efficient in reducing cucumber and wheat powdery mildew and rice brown spot (Rezende et al., 2009) diseases severity due to a direct effect $\mathrm{Si}$ on pathogen and enhancing the activity of peroxidase (POX), polyphenol oxidase (PPO) and chitinase. Cherif and Belanger (1992) and Cherif et al. (1994) added that, $\mathrm{Si}$ amended plants were found to be controlling both soil born and foliar fungal diseases of several crops by phenolic laden cells which seriously damaged fungal hyphae and antifungal fungi toxic phenolics.

Silicon could induce defense responses similar to systemic acquired resistance. Several studies showed that lower disease severity in the Si treated plants was in line with higher activity of protective enzymes (POX, PPO, PAL) in leaves of rice ( Datnoff et al., 2007), wheat (Nanayakkara et al., 2008a), cucumber (Cherif \& Belanger 1992 and Rezende et al., 2009) as well as chitinase and glucanase in pea (Dann and Muir, 2002). They added that, these enzymes had important role in regulation the production of accumulation of antifungal compounds such as phenolics, lignin, phytoalexins (rice blast), flavonoid phytoalexins (cucumber and wheat powdery mildew) and PR proteins (cucumber, Fawe et al., 1998). Phenolic compounds are important plant secondary metabolites with known biological functions including antimicrobial activity (Casati and Walbot, 2005). Phenolics had been implicated in resistance to ear rots of maize (Classen et al., 1990). Information related to the effect of $\mathrm{Cu}$ and $\mathrm{Si}$ on maize resistance or susceptibility to late wilt is, for the best of our knowledge, lacking in the literature. Therefore, the aim of this study was to investigate the effect of copper sulfates and sodium silicate salts on late wilt disease under field conditions to achieve better disease management.

\section{Materials and Methods}

Reaction of late wilt disease to applied salts

The present work was carried out at the experimental farm of Sakha Agriculture Research Station, Kafr El-Sheikh governorate during 2017, 2018 and 2019 growing seasons under late wilt field disease nursery conditions.

a) Seed coating

Copper sulfates $\left(\mathrm{CuSO}_{4} .5 \mathrm{H}_{2} \mathrm{O}\right.$, El Nasr Pharm. Chem. Co. Production, Egypt) at concentrations of $0.2,0.4,0.6,0.8 \mathrm{~g}$ and sodium silicate $\left(\mathrm{Na}_{2} \mathrm{O}_{3} \mathrm{Si}_{9}\right.$ $\mathrm{H}_{2} \mathrm{O}$, Oxford production, India) at concentrations 
of $0.2,0.4,0.6,0.8$ and $1.0 \mathrm{~g}$ were used as seed coating per $100 \mathrm{~g}$ of maize seeds $c v$. Balady which is susceptible to late wilt disease. These salts were adjusted to obtain the desired concentrations and tested against late wilt disease. Every concentration of the two salts was dissolved at 10 $\mathrm{ml}$ of water with one drop of Arabic gum and then mixed with maize seeds separately and left 24 hours until draying. Every treatment was planting in two rows, $4 \mathrm{~m}$ long, $80 \mathrm{~cm}$ distance apart and sown by 2-3 grains/hill, thinned to one plant/hill after three weeks. Randomized complete block design with three replicates was used. All cultural practices were applied at the proper time. Toxicity of used salts was estimated by counting of maize seedlings after germination process at 15 days from planting and estimating of germination percent. Late wilt disease incidence (DI \%) was estimated as infection percentage after 35 days from flowering (90 days from planting) as well as infection and yield efficiency percentages (Eff \%) as adopted by El-Shafey et al. (1988) as follows:

Infection percentage $(\mathrm{DI} \%)=[$ No. of infected plants / no. of total plants] x100.

Efficiency percentage $=\frac{\boldsymbol{C}-\boldsymbol{T}}{\boldsymbol{C}} \times 100$.

Where: C: control, T: treatment.

Yield was estimated after harvesting for all treatments and control as weight $\mathrm{kg} \mathrm{plot}^{-1}$.

b) Fertilizer application

Certain nutrients of copper sulfates and sodium silicate at concentrations 5, 10, 15, $20 \mathrm{~g}$ and $25 \mathrm{~g}$ of sodium silicate /plot were used as a fertilizer added separately beside to maize seedlings during two irrigations (dates), the first after 18-20 days and second after 33- 35 days from planting to control late wilt disease. Every treatment (plot) was planted in two rows, $4 \mathrm{~m}$ long, $80 \mathrm{~cm}$ distance apart and sown by 2-3 grains per hill, thinned to one plant per hill after three weeks. Randomized complete block design with three replicates was used with the two experiments (dates) separately. All cultural practices were applied at the proper time. Late wilt disease infection and yield were estimated as previously.

\section{Peroxidase and polyphenoloxidase enzyme activity}

Oxidative enzymes activity of peroxidase and polyphenoloxidase were estimated after 10 days from planting of maize leaves samples in season 2019 with $0.6,0.8 \mathrm{~g}$ of copper sulfates and sodium silicate used as seed coating treatment/100 g maize seeds and 15 and $20 \mathrm{~g} /$ plot of both salts as fertilizers method application with first and second irrigates separately. These treatments were selected as the most effective ones against late wilt disease compared with control treatment. Plant material was homogenized at ratio1:2 (w/v) with $0.1 \mathrm{M}$ sodium phosphate buffer , $\mathrm{PH}$ 7.1. Extraction filtered through nylon cloth and centrifuged at $12000 \mathrm{xg}$, for $30 \mathrm{~min}$ at 4 ${ }^{\circ} \mathrm{C}$ to preparation of plant extracts. Oxidative enzyme activity of peroxidase was estimated and expressed as changes of absorbance at 470 $\mathrm{nm}$ (optical density, OD / min /g fresh weight) at one and three min and expressed as unit $\mathrm{mg}$ protein / g fresh weight as methods adopted by Nakano and Asada (1981) and polyphenol oxidase enzyme was measured at $495 \mathrm{~nm}$ (optical density, OD $/ \mathrm{min} / \mathrm{g}$ fresh weight) as methods of Matta and Dimond (1963) at one and three min. using spectrophotometer (Spectronic $21 \mathrm{D})$. The increase of enzymes activity was determined as enzyme efficiency percentage using above efficiency equation.

\section{Proximate chemical composition}

Maize leaf samples in season 2018 were subjected for all next chemical analysis and were taken after 10 days from treating by salts of $0.8 \mathrm{~g}$ of copper sulfates used as seed coating treatment/ $100 \mathrm{~g}$ maize seeds, $20 \mathrm{~g} /$ plot of both copper sulfates and sodium silicate as fertilizers method application added at first irrigation and $20 \mathrm{~g} /$ plot of sodium silicate at second irrigation separately. These treatments were selected as the most effective ones against late wilt disease compared to control treatment. Moisture, crude protein content ( $\mathrm{N}$ x 5.95), crude fat and ash of the samples were determined and calculated according to the methods described by AOAC (2005). Total carbohydrates content was calculated by difference as follows: Total carbohydrates $\%$ $=100-($ crude protein $\%+$ crude fat ether extract $\%$ + ash $\%)$ on dry weight.

\section{Extraction of total phenolic compounds}

Total phenolic compounds were extracted according to the methods described by $\mathrm{Hu}$ and $\mathrm{Xu}$ (2011). Ground maize leaves were subjected to phenolics extraction using methanol $95 \%$. The extraction process was continued for $24 \mathrm{~h}$ at room temperature by stirring in the solvent. The extracts were centrifuged at $4000 \mathrm{rpm}$ for $15 \mathrm{~min}$ and filtered through filter paper (Whatman No. 41). The solvent was removed from the extracts using a rotary evaporator at $40^{\circ} \mathrm{C}$ under vacuum. The extracts were further dried using vacuum oven 
at $40{ }^{\circ} \mathrm{C}$ and then kept in dry clean closed black glass bottle at $4{ }^{\circ} \mathrm{C}$ for further analysis.

\section{Determination of total phenolic}

Total phenol compounds content was determined according to Singleton (1999). The method is based on the color reaction of FolinCiocalteu reagent with hydroxyl groups. Reaction absorbance was measured at $760 \mathrm{~nm}$ using a spectrophotometer. The results were expressed as $m g$ tannic acid per $100 \mathrm{~g}$ of extract.

Antioxidant activity assay

Antioxidant activity was measured using the 2,2-diphenyl-1- picrylhydrazyl (DPPH) method described by Soler-Rivas et al. (2000).

\section{Statistical analysis}

Data were analyzed statistically using the analysis of variance and the means were further tested using the least significant difference test (LSD) as outlined by Steel and Torrie (1980).

\section{Results and Discussion}

Response of late wilt disease to salts application

\section{a. Seed coating}

From data in Fig. 1, maize seeds coated by salts of copper sulfates and sodium silicate at the used

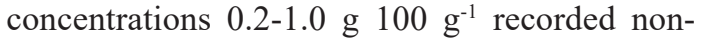
significant differences in germination percentage between the tested salts and control in the two tested seasons and ranged from 58.33-71.66
$\%$. So, these salts with desired concentrations exhibited non phytotoxic to maize seeds and could be used to test against late wilt disease and his pathogen without toxicity to maize seeds.

Results in Table 1 recorded that, maize seed coated by salts of copper sulfates and sodium silicate at cons. 0.2-1.0 g / $100 \mathrm{~g}$ seeds led to reduce late wilt disease infection percentage under field disease nursery conditions during two tested seasons of 2017 and 2018 compared to control treatment. The cons. of $0.8 \mathrm{~g}$ of copper sulfates, 0.8 and $1.0 \mathrm{~g}$ of sodium silicate were the most effective ones in reducing of late wilt disease than the others ones in each particular salts. The infection percentages of these treatments ranged from $2.12-10.33 \%$ in comparison of $11.11-20.04 \%$ of control in the two growing seasons. Reduction of the disease was reflected in enhancement of yield with this treatments ie.7.45$9.30 \mathrm{~kg} /$ plot and efficiency (increase) ranged from $17.50-26.02 \%$ during two tested seasons of 2017 and 2018. At all salts, efficacy against the disease infection recorded satisfactory effect and ranged from $42.31-80.09 \%$ in the two seasons, as well as, high conc. recorded high efficiency. At all treatments, the highest yield efficiency was recorded with $0.8 \mathrm{~g}$ sodium silicate i.e. $26.02 \%$ in the two tested seasons, while most of other treatments showed increase of the yield with nonsignificant in comparing of control.

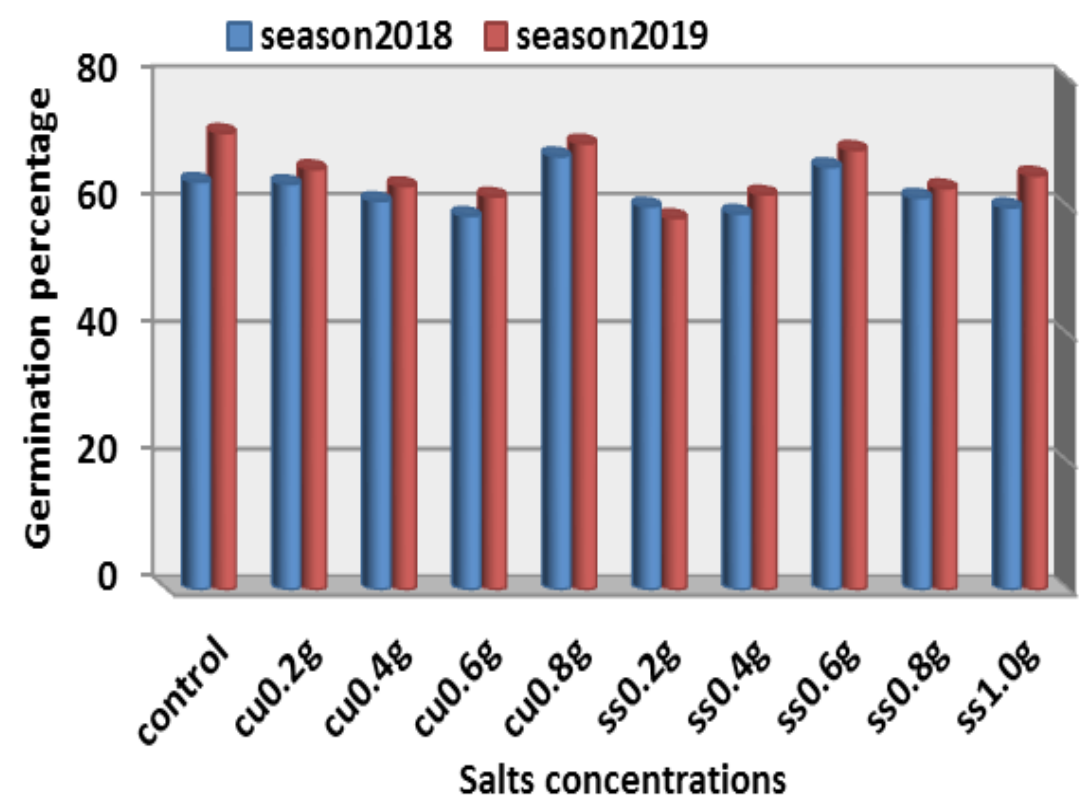

Fig. 1. Effect of seed coating with copper sulfate $(\mathrm{Cu})$ and sodium silicate (ss) on germination percent of maize in both growing seasons 2018 and 2019

Env. Biodiv. Soil Security Vol. 3 (2019) 
TABLE 1. Effect of seeds coating by copper sulfate and sodium silicate salts of maize on late wilt disease in both growing seasons 2017 and 2018

\begin{tabular}{|c|c|c|c|c|c|}
\hline \multirow{2}{*}{\multicolumn{2}{|c|}{$\begin{array}{c}\text { Salts } \\
\text { Concentrations } \\
\text { g /100 g maize seeds }\end{array}$}} & \multirow[b]{2}{*}{$\begin{array}{c}\text { Infection } \\
(\%)\end{array}$} & \multicolumn{3}{|c|}{ Season 2017} \\
\hline & & & $\begin{array}{c}\text { Efficiency } \\
(\%)\end{array}$ & $\begin{array}{c}\text { Yield } \\
\text { kg plot }^{-1}\end{array}$ & $\begin{array}{c}\text { Efficiency } \\
(\%)\end{array}$ \\
\hline \multirow{5}{*}{$\begin{array}{l}\text { Copper } \\
\text { sulfate }\end{array}$} & 0.2 & $4.78 b$ & $56.97 \mathrm{f}$ & $8.47 \mathrm{bcd}$ & $9.57 f$ \\
\hline & 0.4 & $5.92 \mathrm{c}$ & $46.71 \mathrm{~g}$ & $8.13 \mathrm{~cd}$ & $5.17 \mathrm{~h}$ \\
\hline & 0.6 & $4.95 \mathrm{~cd}$ & $55.44 \mathrm{f}$ & $9.23 \mathrm{a}$ & $19.4 \mathrm{~b}$ \\
\hline & 0.8 & $2.37 \mathrm{fg}$ & $78.66 \mathrm{bc}$ & $9.30 \mathrm{a}$ & $20.31 \mathrm{a}$ \\
\hline & 0.2 & $4.07 \mathrm{de}$ & $63.36 \mathrm{e}$ & $8.31 \mathrm{~cd}$ & $7.50 \mathrm{~g}$ \\
\hline \multirow{4}{*}{$\begin{array}{l}\text { Sodium } \\
\text { silicate }\end{array}$} & 0.4 & $2.59 \mathrm{ef}$ & $76.68 \mathrm{c}$ & $8.27 \mathrm{~cd}$ & $6.98 \mathrm{~g}$ \\
\hline & 0.6 & $3.56 \mathrm{def}$ & $67.95 \mathrm{~d}$ & $8.52 \mathrm{abcd}$ & $10.21 \mathrm{e}$ \\
\hline & 0.8 & $2.12 \mathrm{fg}$ & $80.09 \mathrm{a}$ & $8.91 \mathrm{abc}$ & $15.26 \mathrm{~d}$ \\
\hline & 1.0 & $2.29 \mathrm{fg}$ & 79.38ab & $9.16 \mathrm{ab}$ & $18.49 \mathrm{c}$ \\
\hline \multirow[t]{3}{*}{ Control } & water & $11.11 \mathrm{a}$ & - & $7.73 d$ & - \\
\hline & & & Season 2018 & & \\
\hline & 0.2 & $11.56 \mathrm{~b}$ & $42.31 \mathrm{i}$ & $6.63 \mathrm{cde}$ & $4.36 \mathrm{~g}$ \\
\hline \multirow{3}{*}{$\begin{array}{l}\text { Copper } \\
\text { sulfate }\end{array}$} & 0.4 & $8.66 \mathrm{bc}$ & $56.78 \mathrm{c}$ & $5.77 \mathrm{e}$ & - \\
\hline & 0.6 & $9.42 b c$ & $54.89 \mathrm{e}$ & $7.36 \mathrm{ab}$ & $16.08 \mathrm{~d}$ \\
\hline & 0.8 & $6.66 \mathrm{bc}$ & $66.76 \mathrm{~b}$ & $7.60 \mathrm{a}$ & $19.87 b$ \\
\hline \multirow{5}{*}{$\begin{array}{l}\text { Sodium } \\
\text { silicate }\end{array}$} & 0.2 & $8.72 b c$ & $56.48 \mathrm{~d}$ & $6.22 \mathrm{e}$ & - \\
\hline & 0.4 & $11.24 b c$ & $43.91 \mathrm{~h}$ & $6.96 \mathrm{bcd}$ & $9.77 f$ \\
\hline & 0.6 & $10.17 b c$ & $49.25 f$ & $7.12 \mathrm{bc}$ & $12.30 \mathrm{e}$ \\
\hline & 0.8 & $10.33 b c$ & $48.45 \mathrm{~g}$ & $7.99 a$ & $26.02 \mathrm{a}$ \\
\hline & 1.0 & $5.34 \mathrm{c}$ & $73.35 \mathrm{a}$ & $7.45 \mathrm{ab}$ & $17.50 \mathrm{c}$ \\
\hline Control & water & $20.04 \mathrm{a}$ & - & $6.34 \mathrm{cde}$ & - \\
\hline
\end{tabular}

In the same column, means followed by the same letter are not significantly different according to DMRT at $5 \%$ level of significance.

\section{b1. Fertilizer at first irrigation}

Present data in Table 2 confirmed that, using certain nutrients of copper sulfates and sodium silicate salts as a fertilizer which added at first irrigate beside maize seedlings led to retarding of late wilt disease in the field and caused reduction of infection percentage in the growing seasons of 2017 and 2018. The highest retarding and the lowest infection percentage was recorded with used cons. of 20 and $25 \mathrm{~g} / \mathrm{plot}$ of copper sulfates and sodium silicate, respectively and ranged from $4.15-8.83 \%$ compared to $11.11-20.04 \%$ of control. The above best treatments reduced the disease and their efficiency ranged, i.e. 55.93-77.29\%. In the most cases, other treatments recorded retarding of the disease infection with exception of $5 \mathrm{~g}$ of copper sulfates in the first seasons and ranged from 4.30-12.03 and disease infection efficacy (reduction) ranged from 39.97-64.37\%.

Generally, copper sulfate was more effective against late wilt disease than sodium silicate. It was recorded high retarding of late wilt disease especially in the second season and enhancement of the yield in comparison of control and other treatments when applied at $20 \mathrm{~g} /$ plot in the two tested seasons followed by $15 \mathrm{~g}$ of its. Since, 20 and 
$25 \mathrm{~g}$ of sodium silicate showed yield enhancement in the second seasons only. At all treatments, yield efficiency ranged from $1.42-29.47 \%$.

\section{b2. Fertilizer at second irrigation}

Results in Table 3 recorded that, all tested salts can cause a reduction of late wilt disease when added as fertilizer at second irrigate under field conditions with exception of $5 \mathrm{~g}$ of copper sulfates in the first season. Increasing of salts cons. led to increase the retarding of late wilt disease and reduction of infection percentage. The most effective ones against the disease infection in the two tested seasons were $25 \mathrm{~g}$ of sodium silicate and $20 \mathrm{~g}$ of copper sulfates. Also, other treatments showed positive effect in this respect. For all salts treatments, infection percentage ranged from
3.62-12.38\% comparing with 11.11 and 20.04 for control. Efficiency of salts fertilizer application against the disease showed differences in their effect. The highest salts efficiency one was copper sulfates $(20 \mathrm{~g})$ i.e. $73.25 \%$ followed by sodium silicate (25 g) i.e. $70.20 \%$ - in the second season while the lowest efficiency one was recorded with $10 \mathrm{~g}$ of copper sulfates i.e. $9.00 \%$ in the first season. Others treatments showed infection efficiency ranged from $26.46-70.60 \%$. As to yield, the increase was recorded only with application of 20 and $25 \mathrm{~g}$ of sodium silicate in the two tested seasons and 15 and $20 \mathrm{~g}$ of copper sulfates in the second season only. The response of yield to application this above best treatments expressed as efficiency was ranged from $14.12-30.31 \%$ and from $1.40-11.26 \%$ with others.

TABLE 2. Effect of fertilizer by copper sulfate and sodium silicate salts of maize at first irrigation late wilt disease in seasons 2017 and 2018

\begin{tabular}{|c|c|c|c|c|c|}
\hline \multirow{2}{*}{\multicolumn{2}{|c|}{$\begin{array}{c}\text { Salts } \\
\text { Concentrations } \\
\text { g/plot }\end{array}$}} & \multicolumn{4}{|c|}{ Season 2017} \\
\hline & & $\begin{array}{c}\text { Infection } \\
(\%)\end{array}$ & $\begin{array}{c}\text { Efficiency } \\
(\%)\end{array}$ & $\begin{array}{c}\text { Yield/plot } \\
\text { kg }\end{array}$ & $\begin{array}{c}\text { Efficiency } \\
(\%)\end{array}$ \\
\hline \multirow{5}{*}{$\begin{array}{l}\text { Copper } \\
\text { sulfate }\end{array}$} & 5 & $10.21 \mathrm{ab}$ & $8.10 \mathrm{i}$ & $6.18 \mathrm{~d}$ & - \\
\hline & 10 & $6.26 \mathrm{c}$ & $43.65 \mathrm{~d}$ & $6.58 \mathrm{bcd}$ & $4.11 \mathrm{~d}$ \\
\hline & 15 & $4.30 \mathrm{~d}$ & $61.29 b$ & $6.80 \mathrm{~b}$ & $7.59 b$ \\
\hline & 20 & $4.15 \mathrm{~d}$ & $62.64 a$ & $7.59 a$ & $20.09 \mathrm{a}$ \\
\hline & 5 & $8.99 b$ & $19.08 \mathrm{~h}$ & $6.41 \mathrm{~cd}$ & $1.42 \mathrm{e}$ \\
\hline \multirow{3}{*}{$\begin{array}{l}\text { Sodium } \\
\text { silicate }\end{array}$} & 10 & $6.43 c$ & $42.12 \mathrm{e}$ & $6.29 \mathrm{~cd}$ & - \\
\hline & 15 & $6.52 \mathrm{c}$ & $41.31 \mathrm{f}$ & $6.56 \mathrm{bcd}$ & $4.11 \mathrm{~d}$ \\
\hline & 20 & $6.60 \mathrm{c}$ & $40.59 \mathrm{~g}$ & $6.58 \mathrm{bcd}$ & $3.79 \mathrm{~d}$ \\
\hline \multirow{3}{*}{ control } & 25 & $4.44 d$ & $60.03 c$ & $6.71 b c$ & $6.17 \mathrm{~d}$ \\
\hline & - & $11.11 \mathrm{a}$ & - & $6.32 \mathrm{~cd}$ & - \\
\hline & & \multicolumn{3}{|c|}{ Season 2018} & \\
\hline \multirow{4}{*}{$\begin{array}{l}\text { Copper } \\
\text { sulfate }\end{array}$} & 5 & $7.78 b c$ & $61.17 \mathrm{~d}$ & $4.99 \mathrm{e}$ & - \\
\hline & 10 & $7.16 \mathrm{bc}$ & $64.27 \mathrm{c}$ & $5.90 \mathrm{bcd}$ & $6.69 \mathrm{c}$ \\
\hline & 15 & $7.14 b c$ & $64.37 \mathrm{~b}$ & $6.44 \mathrm{ab}$ & $16.45 \mathrm{ab}$ \\
\hline & 20 & $4.55 c$ & $77.29 \mathrm{a}$ & $6.40 \mathrm{ab}$ & $15.73 \mathrm{ab}$ \\
\hline \multirow{5}{*}{$\begin{array}{l}\text { Sodium } \\
\text { silicate }\end{array}$} & 5 & $12.03 b$ & $39.97 \mathrm{i}$ & $5.15 \mathrm{de}$ & - \\
\hline & 10 & $9.16 b c$ & $54.29 f$ & $5.58 \mathrm{bcd}$ & $6.01 \mathrm{c}$ \\
\hline & 15 & $11.60 \mathrm{bc}$ & $42.15 \mathrm{~h}$ & $6.10 \mathrm{bc}$ & $10.30 \mathrm{bc}$ \\
\hline & 20 & $10.97 \mathrm{bc}$ & $45.25 \mathrm{~g}$ & $6.55 \mathrm{ab}$ & $18.44 \mathrm{a}$ \\
\hline & 25 & $8.83 b c$ & $55.93 \mathrm{e}$ & $7.16 \mathrm{a}$ & $29.47 \mathrm{a}$ \\
\hline Control & - & $20.04 \mathrm{a}$ & - & $5.53 \mathrm{cde}$ & - \\
\hline
\end{tabular}

In the same column, means followed by the same letter are not significantly different according to DMRT at $5 \%$ level of significance. 
TABLE 3. Effect of fertilizer by copper sulfate and sodium silicate salts of maize at second irrigation late wilt disease in seasons 2017 and 2018

\begin{tabular}{|c|c|c|c|c|c|}
\hline \multirow{2}{*}{\multicolumn{2}{|c|}{$\begin{array}{c}\text { Salts } \\
\text { Concentrations } \\
\text { g/plot }\end{array}$}} & \multicolumn{4}{|c|}{ Season 2017} \\
\hline & & $\begin{array}{c}\text { Infection } \\
\%\end{array}$ & $\begin{array}{c}\text { Efficiency } \\
\%\end{array}$ & $\begin{array}{c}\text { Yield/plot } \\
\text { kg }\end{array}$ & $\begin{array}{c}\text { Efficiency } \\
\%\end{array}$ \\
\hline \multirow{5}{*}{$\begin{array}{l}\text { Copper } \\
\text { sulfate }\end{array}$} & 5 & $11.58 \mathrm{a}$ & - & $6.49 \mathrm{~cd}$ & $1.40 \mathrm{f}$ \\
\hline & 10 & $10.11 b$ & $9.00 \mathrm{~h}$ & $6.52 \mathrm{~cd}$ & $1.87 \mathrm{e}$ \\
\hline & 15 & $8.17 \mathrm{c}$ & $26.46 \mathrm{~g}$ & $6.27 \mathrm{~cd}$ & - \\
\hline & 20 & $6.32 \mathrm{~d}$ & $43.11 \mathrm{e}$ & $6.85 \mathrm{bc}$ & $7.03 \mathrm{c}$ \\
\hline & 5 & $7.52 \mathrm{c}$ & $32.31 \mathrm{f}$ & $6.49 \mathrm{~cd}$ & $1.40 \mathrm{f}$ \\
\hline \multirow{4}{*}{$\begin{array}{l}\text { Sodium } \\
\text { silicate }\end{array}$} & 10 & $5.44 d$ & $51.03 \mathrm{c}$ & $6.05 \mathrm{~d}$ & - \\
\hline & 15 & $5.56 \mathrm{~d}$ & $49.95 d$ & $6.76 \mathrm{~cd}$ & $5.62 \mathrm{~d}$ \\
\hline & 20 & $5.76 \mathrm{~d}$ & $48.15 d$ & $7.64 \mathrm{a}$ & $19.37 \mathrm{a}$ \\
\hline & 25 & $3.62 \mathrm{e}$ & $67.41 \mathrm{a}$ & $7.55 \mathrm{ab}$ & $17.96 \mathrm{~b}$ \\
\hline \multirow[t]{2}{*}{ Control } & - & $11.11 \mathrm{a}$ & - & $6.40 \mathrm{~cd}$ & - \\
\hline & & \multicolumn{3}{|c|}{ Season 2018} & \\
\hline \multirow{4}{*}{$\begin{array}{l}\text { Copper } \\
\text { sulfate }\end{array}$} & 5 & $12.38 \mathrm{~b}$ & $38.22 \mathrm{~h}$ & $6.87 \mathrm{~cd}$ & $9.04 \mathrm{~g}$ \\
\hline & 10 & $9.52 b c$ & $52.49 \mathrm{e}$ & $6.82 \mathrm{~cd}$ & $8.25 \mathrm{~h}$ \\
\hline & 15 & $5.89 \mathrm{~cd}$ & $70.60 \mathrm{~b}$ & $7.19 b c$ & $14.12 d$ \\
\hline & 20 & $5.38 \mathrm{~cd}$ & $73.25 \mathrm{a}$ & $7.95 \mathrm{ab}$ & $26.19 b$ \\
\hline \multirow{5}{*}{$\begin{array}{l}\text { Sodium } \\
\text { silicate }\end{array}$} & 5 & $6.24 \mathrm{~cd}$ & $68.86 \mathrm{c}$ & $7.01 \mathrm{~cd}$ & $11.26 \mathrm{e}$ \\
\hline & 10 & $9.66 \mathrm{bc}$ & $51.79 \mathrm{f}$ & $6.93 \mathrm{~cd}$ & $10.00 \mathrm{f}$ \\
\hline & 15 & $9.82 b c$ & $50.99 \mathrm{~g}$ & $7.01 \mathrm{~cd}$ & $11.26 \mathrm{e}$ \\
\hline & 20 & $8.85 b c$ & $55.83 \mathrm{~d}$ & $7.51 \mathrm{abc}$ & $19.20 \mathrm{c}$ \\
\hline & 25 & $5.97 \mathrm{~cd}$ & $70.20 \mathrm{~b}$ & $8.21 \mathrm{a}$ & $30.31 \mathrm{a}$ \\
\hline Control & - & $20.04 \mathrm{a}$ & - & $6.30 \mathrm{~d}$ & - \\
\hline
\end{tabular}

In the same column, means followed by the same letter are not significantly different according to DMRT at $5 \%$ level of significance.

In conclusion, copper sulfate and sodium silicate salts seed coating with desired concentrations exhibited non phytotoxic to maize seeds and could be used to test against late wilt disease and his pathogen without toxicity to maize seeds, Boros and Micle (2015) found that, germination rate of several crops including maize is reduced by $\mathrm{Cu}$ oxidative stress when present in high concentration in soil, Stephenson et al. (2001). Salts seed coating and a fertilizer to maize plants can cause retarding of late wilt disease and / or reduction of infection efficiency (DI \%) under field disease nursery conditions; this led to partially enhancement of yield with some treatments. Present results in agreement with Singh and Siradhana (1990) they reported that, micronutrients of $\mathrm{Cu}, \mathrm{Fe} \mathrm{Mn}$, and $\mathrm{Zn}$ were reduced late wilt disease infection, to direct application on plants in the field, used for seed treatment to prevent infection by plant pathogens, Verma et al. (2011). $\mathrm{Cu}$ formulations $\mathrm{SO}_{4}$ used as biocide to control plant pathogenic fungi, bacteria, Capinera and Dickens (2016). Consequently, Cupric sulfate was the most effective one in retarding of many diseases i.e., powdery mildew under field conditions of sugar beet (Eliwa et al., (2018), Farahat and Salama (2019), cucumber plants, Reuveni et al. (1997) and cercospora field 
disease severity, Farahat et al. (2011) and Elmoghazy et al. (2011). Moreover, Precigout et al. (2017) added that, use of fertilizers could reduce biotrophic fungal epidemics. As $\mathrm{Cu}$ mechanisms effects, Fleming and Trevors (1989) showed that, copper acts as biocide to plant pathogens at high conc. due to its interaction with nucleic acid, disruption of enzymes active sites, interference with energy transport system, and disruption of cell membrane, as well as, antimicrobial with high toxicity, low costs, low mammalian toxicity of the fixed compounds and their chemical stability, Lamichhane et al. (2018).

Present results recorded essential role of silicon in late wilt disease infection efficiency reduction, this results supported by many researchers in group, they reported that $\mathrm{Si}$ soil fertilization significantly reduced many diseases susceptibility, $i$ e. neck blast, brown spot (Datnoff et al., 1991); root mortality, root decay by stimulating host plant defenses (Cherif and Belanger ,1992); crown and root rot of Pythium (Cherif et al., 1994), Fusarium wilt (Belanger et al., 1995), earlier soil and soilless Si (sodium and calcium silicate) application to enhance disease control (Datnoff et al., 2007). Additionally, Si reduced the severity of important diseases, such as blast and sheath blight of rice, powdery mildew of wheat, barley, cucumber and tomato ; ring spot in sugarcane ; rust of cowpea; gray leaf spot of ryegrass and back sigatoka of banana (Datnoff et al., 2007 ; Nanayakkara et al., 2008 a,b ; Rezende et al. , 2009 and Kablan et al, 2012). Also, there were several favorable effects due to proper $\mathrm{Si}$ nutrition on growth, development and health status of plants including increasing of growth, production and photosynthesis , (Datnoff et al., 2007).

Yield enhancement was recorded with present salts application and achieved by researchers, i.e. Winslow (1992) reported that, increased yield considerably in response to $\mathrm{Si}$ fertilization and subsequently, final disease progress and disease severity were reduced resulting in improving yield and quality (Datnoff et al., 2001). Cai et al. (2008), Hayasaka et al. (2008) and Datnoff (2012) suggested two hypothesis to explain how $\mathrm{Si}$ enhance plant resistance against pathogen infection : silicon layers (insoluble) deposited in epidermal cells preventing penetration by the pathogen (mechanical barrier hypothesis) and effects the response of plant at biochemical and molecular levels. Also, Si played a major

Env. Biodiv. Soil Security Vol. 3 (2019) role in suppressing disease of plants grown in greenhouse and field conditions fellowship increase of crop yield and pathogen resistance. In addition, Locke et al. (2004 and 2008) reported that, Si can lead to enhanced plant resistance to fungal attack, Botrytis cinerea, in herbaceous crops and controlled powdery mildew of zinnias by delaying disease development and lesion size was restricted, there is potential to utilize silicon in management practices to alleviate certain plant disease stresses. It is likely that silicon was incorporated into cell walls as silicon aromatic ring associations between lignin and carbohydrate (Inanaga and Okasaka, 1995). Silicon compounds have been suggested to play a role in limiting lesion expansion and may reduce the infection efficiency and inoculum production for secondary infection, Seebold et al. (2001). Kanto et al. (2004) did not observe any effect of potassium silicate solution on conidial germination of $S$. aphanis var aphanis suggesting that soluble silicon did not directly act against infection of powdery mildew of strawberry but may change the chemical composition of the cuticle layer that inhibit conidia germination. Soils and soilless mixes of Si suppress a number of root diseases in both dicots and monocots under greenhouse and field conditions, Datnoff et al. (2012). Liang et al. (2005) and Guevel et al. (2007) found that, Si root applied was efficient in reducing cucumber and wheat powdery mildew diseases severity due to a direct effect $\mathrm{Si}$ on pathogen . Controlling both soil born and foliar fungal diseases of several crops by $\mathrm{Si}$ amendment was provided with effectiveness, Cherif and Belanger (1992) and Cherif et al. (1994). Alternative control of late wilt in maize was achieved by El-moghazy et al. (2017). Elbasiouny and Elbehiry (2019) added that, copper micronutrient was needed and may be toxic to organisms

\section{Peroxidase and polyphenol oxidase enzymes activity}

Since enzymes of peroxidase and polyphenol oxidase played an important and essential role in plant defense. So, activity of these enzymes was estimated with some cons. of salts which recorded retarding of late wilt disease in the field. Data in Table 4 showed that, all tested cons. of used salts led to significantly increase of PO enzyme activity with seed coating application. Copper sulfates at $0.6 \mathrm{~g} / 100 \mathrm{~g}$ seeds recorded the highest activity values in the two estimation periods 1 and $3 \mathrm{~min}$ followed by $0.8,0.6 \mathrm{~g}$ of sodium silicate and 0.8 $\mathrm{g}$ of copper sulfates, respectively in comparison 
of control treatment. At all, PO activity ranged from $0.755-1.373$ and $0.709-0.716(\mathrm{OD} / \mathrm{min} / \mathrm{g}$ fresh weight) of salts and control, respectively. Salts seeds coating application led to increase of PO activity efficiency from 6.48 to $92.52 \%$. As to PPO enzyme activity, $0.6 \mathrm{~g}$ of copper sulfates followed by $0.6 \mathrm{~g}$ of sodium silicate followed by $0.8 \mathrm{~g}$ of copper sulfates were recorded appositive activity in 1 and 3 min estimations periods, while the reverse was true of $0.8 \mathrm{~g}$ of sodium silicate. PPO activity of all tested salts ranged from 1.223 -1.986 in comparison of 1.203-1.263 (OD/ $\mathrm{min} / \mathrm{g}$ fresh weight) of control and the activity increase(efficiency) ranged from 1.03 to $61.76 \%$. In general, PO recorede activity more than PPO.

Data presented in Table 5 recorded that, salts of copper sulfates and sodium silicate as fertilizer at the first irrigate exhibited activator of PO and PPO enzymes. $15 \mathrm{~g}$ of copper sulfates showed the highest PO activity, while $15 \mathrm{~g}$ of sodium silicate recorded the highest one in PPO activity. All tested cons. of salts led to enhancement of PO activity while the reverse was true in case of $20 \mathrm{~g}$ of copper sulfates of PPO activity. PO activity ranged from 1.003-1.243, since PPO activity ranged from $1.016-1.682(\mathrm{OD} / \mathrm{min} / \mathrm{g}$ fresh weight) and the lowest ones recorded with control. These salts recorded increase of PO and PPO activities (efficiency) from 0.70 to $25.17 \%$ and from 0.19 to $48.71 \%$, respectively. Sodium silicate $(15 \mathrm{~g})$ exhibited more activator of PPO than $\mathrm{PO}$, because it is recorded the highest activity increase (efficiency) percentage i.e. 48.71\%.

TABLE 4. Peroxidase and polyphenol oxidase enzymes activity of maize plants treated by copper sulfate and sodium silicate salts as seeds coating

\begin{tabular}{|c|c|c|c|c|c|c|c|c|c|}
\hline \multirow{2}{*}{\multicolumn{2}{|c|}{$\begin{array}{c}\text { Salts } \\
\text { concentrations } \\
\mathrm{g} / 100 \mathrm{~g} \text { seeds }\end{array}$}} & \multicolumn{4}{|c|}{$\mathrm{PO} / \mathrm{OD} / \mathrm{min} / \mathrm{g}$ fresh weight } & \multicolumn{4}{|c|}{$\mathrm{PPO} / \mathrm{OD} / \mathrm{min} / \mathrm{g}$ fresh weight } \\
\hline & & \multirow{3}{*}{$\begin{array}{l}1 \mathbf{m i n} \\
1.365 \mathrm{a} \\
0.755 \mathrm{~d}\end{array}$} & \multirow{3}{*}{$\begin{array}{c}\text { Eff.\% } \\
92.52 \mathrm{a} \\
6.48 \mathrm{~d}\end{array}$} & \multirow{3}{*}{$\begin{array}{l}3 \mathrm{~min} \\
1.373 \mathrm{a} \\
0.777 \mathrm{c}\end{array}$} & \multirow{3}{*}{$\begin{array}{c}\text { Eff. \% } \\
\begin{array}{c}91.75 \mathrm{a} \\
8.52 \mathrm{c}\end{array}\end{array}$} & \multirow{3}{*}{$\begin{array}{l}1 \mathrm{~min} \\
1.946 \mathrm{a} \\
1.493 \mathrm{c}\end{array}$} & \multirow{3}{*}{$\begin{array}{l}\text { Eff. \% } \\
61.76 \mathrm{a} \\
24.01 \mathrm{c}\end{array}$} & \multirow{3}{*}{$\begin{array}{l}3 \mathrm{~min} \\
1.986 \mathrm{a} \\
1.566 \mathrm{c}\end{array}$} & \multirow{2}{*}{$\begin{array}{l}\text { Eff. \% } \\
57.24 \mathrm{a}\end{array}$} \\
\hline Copper & 0.6 & & & & & & & & \\
\hline sulfate & 0.8 & & & & & & & & $23.99 \mathrm{c}$ \\
\hline Sodium & 0.6 & $0.765 \mathrm{c}$ & $7.88 \mathrm{c}$ & $0.766 \mathrm{c}$ & $6.98 \mathrm{~d}$ & $1.643 b$ & $36.56 \mathrm{~b}$ & $1.740 \mathrm{~b}$ & $37.76 b$ \\
\hline silicate & 0.8 & $0.798 b$ & $12.55 \mathrm{~b}$ & $0.823 b$ & $14.94 \mathrm{~b}$ & $1.223 \mathrm{~d}$ & $1.66 \mathrm{~d}$ & $1.276 \mathrm{~d}$ & $1.03 \mathrm{~d}$ \\
\hline Control & - & $0.709 \mathrm{e}$ & - & $0.716 \mathrm{~d}$ & - & $1.203 \mathrm{~d}$ & - & $1.263 \mathrm{~d}$ & - \\
\hline
\end{tabular}

In the same column, means followed by the same letter are not significantly different according to DMRT at $5 \%$ level of significance. . Eff. \%: Efficiency percentage.

TABLE 5. Peroxidase and polyphenol oxidase enzymes activity of maize plants treated by copper sulfate and sodium silicate salts as fertilizer at first irrigate

\begin{tabular}{|c|c|c|c|c|c|c|c|c|c|}
\hline \multirow{2}{*}{\multicolumn{2}{|c|}{$\begin{array}{c}\text { Salts } \\
\text { Concentrations } \\
\text { g/plot }\end{array}$}} & \multicolumn{4}{|c|}{ PO/OD / min /g fresh weight } & \multicolumn{4}{|c|}{$\mathrm{PPO} / \mathrm{OD}$ / min /g fresh weight } \\
\hline & & \multirow{2}{*}{$\begin{array}{c}1 \mathrm{~min} \\
1.243 \mathrm{a}\end{array}$} & \multirow{2}{*}{$\begin{array}{c}\text { Eff.\% } \\
25.17 \mathrm{a}\end{array}$} & \multirow{2}{*}{$\begin{array}{c}3 \mathrm{~min} \\
1.106 \mathrm{a}\end{array}$} & \multirow{2}{*}{$\begin{array}{l}\text { Eff.\% } \\
11.04 \mathrm{a}\end{array}$} & \multirow{2}{*}{$\begin{array}{c}1 \mathrm{~min} \\
1.223 \mathrm{~b}\end{array}$} & \multirow{2}{*}{$\begin{array}{l}\text { Eff. \% } \\
20.61 \mathrm{~b}\end{array}$} & \multirow{2}{*}{$\begin{array}{l}3 \mathrm{~min} \\
1.376 \mathrm{~b}\end{array}$} & \multirow{2}{*}{$\begin{array}{l}\text { Eff. \% } \\
21.66 \mathrm{~b}\end{array}$} \\
\hline Copper & 15 & & & & & & & & \\
\hline sulfate & 20 & $1.006 \mathrm{~d}$ & $1.30 \mathrm{~d}$ & $1.003 \mathrm{~d}$ & $0.70 \mathrm{~d}$ & $1.016 \mathrm{~d}$ & $0.19 \mathrm{~d}$ & $1.133 \mathrm{~d}$ & $1.12 \mathrm{~d}$ \\
\hline \multirow{2}{*}{$\begin{array}{l}\text { Sodium } \\
\text { silicate }\end{array}$} & 15 & $1.018 \mathrm{c}$ & $2.52 \mathrm{c}$ & $1.019 \mathrm{c}$ & $2.31 \mathrm{c}$ & $1.461 \mathrm{a}$ & $44.08 \mathrm{a}$ & $1.682 \mathrm{a}$ & $48.71 \mathrm{a}$ \\
\hline & 20 & $1.063 \mathrm{~b}$ & $7.05 b$ & $1.066 \mathrm{~b}$ & $7.03 b$ & $1.123 \mathrm{c}$ & $10.74 \mathrm{c}$ & $1.291 \mathrm{c}$ & $14.15 \mathrm{c}$ \\
\hline Control & - & $0.993 \mathrm{e}$ & - & $0.996 \mathrm{e}$ & - & $1.014 \mathrm{~d}$ & - & $1.131 \mathrm{~d}$ & - \\
\hline
\end{tabular}

In the same column, means followed by the same letter are not significantly different according to DMRT at $5 \%$ level of significance. . Eff.\%: Efficiency percentage. 
Concerning the effect of salts as fertilizer at second irrigate, results in Table 6 a certain and supported the results in above Tables (4 and 5) and recorded that, adding of copper sulfates and sodium silicate salts at second irrigate to maize plants led to activate of PO and PPO enzymes more than control treatment. $15 \mathrm{~g}$ followed by 20 $\mathrm{g}$ of copper sulfates were more activation of both enzymes than the same ones of sodium silicate, recording the highest enzymes activity values ones. PO and PPO enzymes activity (efficiency) were increased from $0.99-38.69 \%$ and from 2.77-31.71\%, respectively.

Data in Tables 4, 5 and 6 concluded that, salts of copper sulfates and sodium silicate when used as seed coating to maize seeds and as fertilizer at first and second irrigates separately induced PO and PPO enzymes activities in the most cases against $H$. maydis fungus, the causal pathogen of late wilt disease. Copper sulfates and sodium silicate salts seed coating led to increase of PO and PPO enzymes activity (efficiency) more than adding them as fertilizer application method up to 92.52 and $61.76 \%$ comparing up to 25.17 and $48.71 \%$ at first irrigate and up to 38.69 and $31.71 \%$ at second irrigate, respectively. Copper sulfates was more activator to PO and PPO enzymes activity with seed coating and as fertilizer at second irrigate than the first irrigate one with sodium silicate. Generally, low used cons. with three methods application of salts were more activators of enzymes than the highest ones, its defense by induction but highest cons. depend up on toxicity against late wilt disease and his pathogen. The above results supported by Vidhyasekaran (1988) who found that, peroxidase assigned a role in disease resistance and was an important enzyme in the synthesis of lignin and it was also known to catalyze the oxidation of lignin to many mono and diphenols and aromatic amines to highly toxic quinones in the presence of hydrogen peroxide. Copper sulfates was elevated of peroxidase (Farahat and Salama , 2019) and glucanase activity (Reuveni et al., 1997) causing decrease of powdery mildew in sugar beet and cucumber, respectively. Many studies supported the present study and showed the lower disease severity in the Si treated plants was in line with higher activity of protective enzymes (POX, PPO, PAL) in leaves of rice (Datnoff et al., 2007); wheat (Nanayakkara et al. 2008a); cucumber (Cherif and Belanger, 1992 and Rezende et al., 2009) and chitinase and glucanase in pea (Dann and Muir, 2002). They added that, these enzymes had important role in regulation the production of accumulation of antifungal compounds i.e. phenolics, lignin, phytoalexins (rice blast), flavonoidphytoalexins (cucumber and wheat powdery mildew) and PR proteins (cucumber, Fawe et al. 1998). Liang et al. (2005) and Guevel et al. (2007) found that, Si root applied enhancing the activity of POX, PPO and chitinase, causing reduce cucumber and wheat powdery mildew and rice brown spot (Rezende et al. 2009) diseases severity.

TABLE 6. Peroxidase and polyphenol oxidase enzymes activity of maize leaves treated by copper sulfate and sodium silicate salts as fertilizer at second irrigate

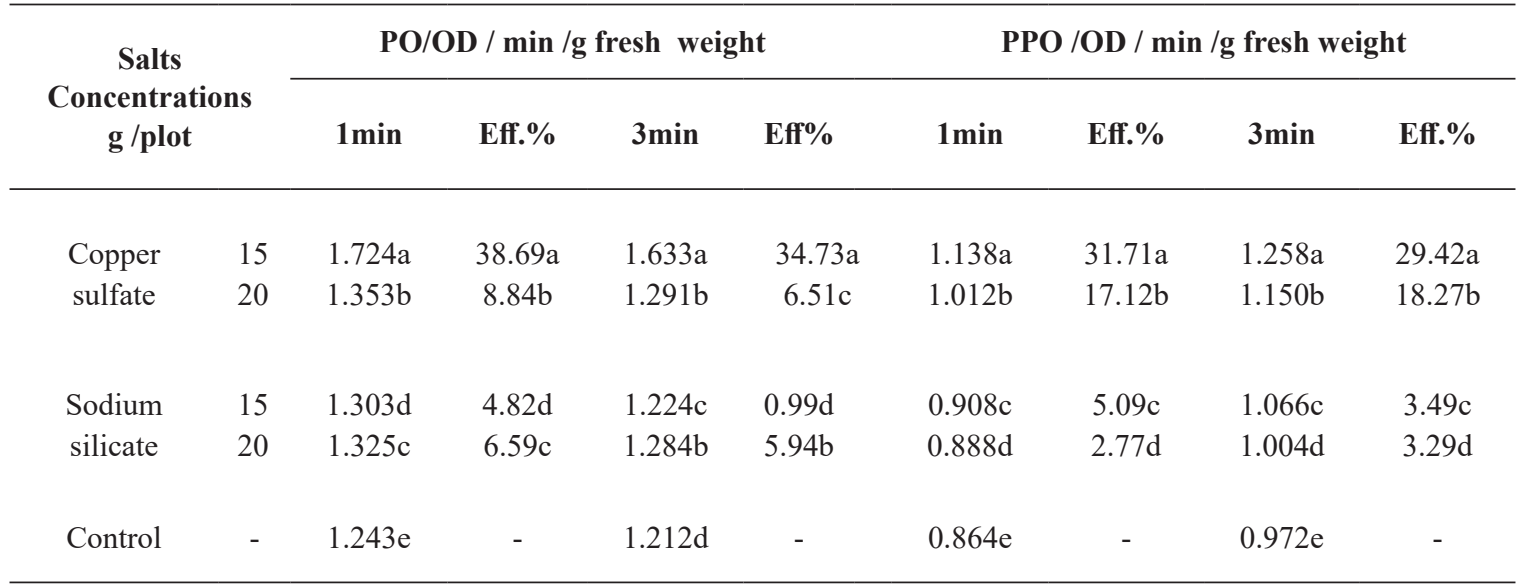

In the same column, means followed by the same letter are not significantly different according to DMRT at 5\% level of significance. . Eff.\%: Efficiency percentage. 
Proximate chemical composition, total phenolics and antioxidant activity of maize leaves

Salts application to maize seeds and /or seedlings led to significantly positive change of gross chemical compositions of maize leaves as showed in Fig. 2. The moisture content ranged from 61 to $68 \%$. However, maize leaves of control treatment contained the highest content of crud protein ie. $13.70 \%$ followed by $20 \mathrm{~g} /$ plot of sodium silicate as fertilizer at second irrigate $(12.90 \%)$ while the lowest value of crud protein was $11.35 \%$ for copper sulfates of $20 \mathrm{~g} /$ plot-fertilizer at first irrigate applications. Apparent also from the same figure that, maize leaves treatments contain from 3.81 to $2.27 \%$ crud fat, 12.85 to $11.94 \%$ ash content, and 73.30 to $72.07 \%$ total carbohydrates. All of these earlier studies indicated an important role for maize proteins in disease resistance. Further investigation found that both constitutive (delay fungal invasion) and inducible (induced antifungal synthesizing) proteins are required for maize resistance (Chen et al. 2001). Present study recorded high proteins with control this return to $H$. maydis fungus proteins with systemic infection by late wilt disease of maize.

Salts application induction of total polyphenols synthesize extracted from different salts treatments of maize leaves with nonsignificant in contents with control as showed in Fig. 2 and ranged from 251.06- 234.06 ( $m g$ tannic acid). Micronutrients are required for polyphenol and phenolic formations metabolism, and crucial for plant defense capability (Huber and Withelm, 1988 and Graham and Webb, 1991). Accumulation of phenols damage fungal hyphae penetrating with phenolic-laden cells of $\mathrm{Si}$ amended plants and conclusively antifungal, Cherif and Belanger (1992) and Cherif et al. (1994). Soluble silicon effects the response of plant at biochemical and molecular level such as increase of plant defense compounds like phenolics , (Hayasaka et al.. 2008 and Datnoff, 2012). Casati and Walbot (2005 reported that, phenolic compounds are important plant secondary metabolites with biological functions including antimicrobial activity. Shery LeClere et al. (2007) and Gembeh et al. (2001) reported that, phenolic-compounds had function in natural resistance of plant pathogens of maize (Classen et al., 1990). Consequently, phenolics may be played essential role in resistance process to maize late wilt disease (Ghazy et al., 2017).

The antioxidant capacities of the maize samples were measured by the radical scavenging activities of the DPPH radical as showed in Fig. 2. All extracts possessed DPPH radical scavenging activity in all treatments with non-significant with control treatment and ranged from 69.68- 75.67 $\%$. The search for sources of natural antioxidants has led to the study of antioxidants in cereals and agro-wastes (Buranov and Mazza, 2008).

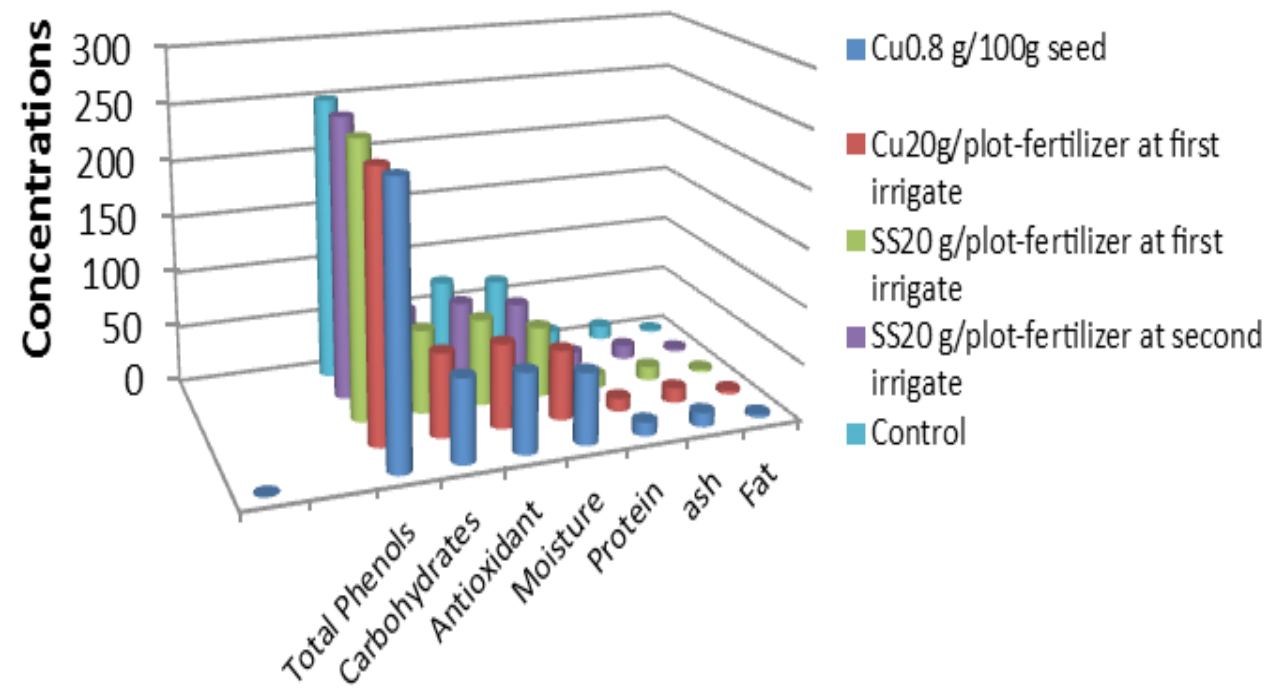

Proximate chemicals

Fig. 2. Effects of different application methods of copper sulfate ( $\mathrm{Cu}$ ) and sodium silicate (ss) salts of phenols, antioxidant and proximate chemicals of maize leaves 


\section{Conclusion}

Given these observation, it was hypothesized that salts of copper sulfates and sodium silicate applied each one may be suppress infection of maize late wilt disease caused by $H$. maydis fungus by activation of oxidative enzymes of peroxidase and polyphenol oxidase, increase of chemical compounds of fat, ash and carbohydrates as well as enhancement of maize yield. It may be possible to use its in an alternate approach.

\section{Acknowledgement}

We would like to express thanks and gratitude to staff members in Plant Pathology and Food Technology, especially, Prof. Mohamed A. ELbana and Associate Researcher Ahmed Sror for helping in chemical analysis, Depts. Sakha Research Station for kind help, faithful effort and advising us during this research.

\section{References}

AOAC, Association of Official Analytical Chemists (2005) Official Methods of Analysis of the Association of Official Analytical Chemists. $18^{\text {th }}$ ed. Washington, DC, USA.

Asawalan, E.F. (2006). Insecticidal and repellent properties of piper guineenese seed oil extract for the control of maize weevil, Sitophilus zeamais. E.J.E.A.F. Chem, 5 (3): 1389-1394.

Belanger ,R.R.; Bowen,P.A.; Ehret, D.L. and Menzies, J. G. (1995) Soluble silicon its role in crop and disease management of greenhouse crops. Plant Disease, 79:4:329-336.

Boros, M. N. and Micle V. (2015) Effect of copperinduced stress on seed germination of maize (Zea mays L.). Agric. Dci. Pract. 3:17-23.

Buranov, A.U. and Mazza, G. (2008). Lignin in straw of herbaceous crops. Ind. Crops Prod. 28: (39): 237-259.

CABI. (1999) Late wilt .Crop Protection Compendium. CAB Int. CD-Rom. Wallingford, UK.

Cai, K.; D. Gao ; I. Shiming ; Z. Resea ; J.Yang and X. Zhu (2008). Physiological and cytological mechanisms of silicon induced resistance in rice against blast disease. Plant Physiol. 134:423-333.

Capinera ,J.L. and Dickens , K.(2016).Some effects of cooper -based fungicides on plant -feeding terrestrial molluscs : a role for repellents in molluscs management . Crop Prot. 83:76-82.

Casati, P. and Walbot , V. (2005) Differential

Env. Biodiv. Soil Security Vol. 3 (2019) accumulation of maysin and rhamnosylisoorientin in leaves of high-altitude landraces of maize after UV-B exposure. Plant Cell Environ. 28:788-799.

Chen Z-Y.; Brown ,R.L. ; Cleveland, T.E.; Damann, K.E. and Russin, J.S. (2001) Comparison of constitutive and inducible maize kernel proteins of genotypes resistanceor susceptible to aflatoxin production . J. Food Prot. 64:1785-1792.

Cherif, M. and Belanger, R.R. (1992). Silicon induced resistance in cucumber plant against Pythium ultimum. Physiol.and Mol.Plant Pathol. 41, 411425.

Cherif, M. ; Asselin, A.and Belanger , R.R. (1994). Defense response induced by soluble silicon in cucumber roots infection by Pythium spp. Phytopathology, 84, 236-242.

Classen, D.; Amason, J.T. ; Serratos, J.A. ; Lambert, J.D.H.; Nozzolillo, C. and Philogene, B.J.R. (1990) Correlation of phenolic acid content of maize to resistance to Sitophilus zeamais, the maize weevil, in Cimmtyt's collections. J. Chem. Ecol. 16, 301-315.

Dann , E. and Muir, S. (2002) Peas grown in media with elevated plant available silicon levels have higher activities of chitinase and glucanase, are less susceptible to a fungal leaf spot pathogen and accumulate more foliar silicon. Asut. Plant Physiol. 31: 9-13.

Datnoff, L.E. (2012) Silicon and biotic stress: suppressing plant disease .visions for a sustainable planet .SA, CSSA and SSSA. International Annual Meetings Oct.21-42, 2012 Cincinnati, Ohio.

Datnoff ,L.E.; Raid ,R.N;Snyder,G.H. and Jones, D.B. (1991) Effect of calcium silicate on blast and brown spot intensities and yield of rice. Plant Disease, 75:7:729-732.

Datnoff, L. E.; Seebolt, K.W. and Correa -Victoria , F.J. (2001) Use of silicon for integrated disease management: Reducing fungicide application an enhancing host resistance. Pages 171-184 In: Silicon in Agriculture .L.E. Datnoff, G.H. Sayder and G.H. Korndorfer, Ed. Elsevier Science Amsterdam, The Netherlands.

Datnoff , L.E.; Rodrigue , F.A. and Seebolt , K.W. (2007) Silicon and Plant Disease. Pages 233-246 in Mineral Nutrition and Plant disease, L.E. Datnoff, W.H. Elmer and D.M. Huber, Ed., American Phytopathological Society, St. Paul. MN.

Eliwa, M.A.; El-Skeikh Aly,M.M.; Abd-Alla,H.M. and 
Galal, A. A. (2018) .Efficacy of certain fungicide alternatives for controlling sugar beet powdery mildew . J. of Phytopath. and Pest Manag. 5:1: 7687.

Elbasiouny, H. and Elbehiry F. (2019) Mobility and potential ecological risk assessment of copper and zinc in alluvial and marine soils in the north Nile Delta, Egypt. Env. Biodiv. Soil Security, 3: 255-268.

El-moghazy, S. M.; El-Kot, G.A. and Hamza, A. M. (2011). Control of sugar beet leaf spot disease caused by the fungus Cercospora beticola (Sacc) .J. Plant Proc. and Path. Mansoura Univ. 2:11: 1037-1047.

El-Shafey, H.A. and Claflin, L.E.(1999) Late wilt. In White, D.G. (Ed) Compendium of Maize Disease $3^{\text {rd }}$ ed. American Phytopathological Society. APS Press, St Paul, . pp 43-44 Mn.

El-Shafey, H.A.; El-Shorbagy F.A.; Kalil, I.I. and El-Assuity , E.M. (1988) Additional sources of resistances to late wilt disease of maize caused by Cephalosporium maydis. Agic .Res. Rev. 66: 221230.

Farahat,G.A; Salama, N.H.H. and Shahin, A.A. (2011) Effect of cercosporin toxin on sugar beet plants and control of cercospora leaf spot disease by micronutrients \& phosphate and plant hormones in the field. J. Agric. Res. Kafer El-Seikh Univ. 37 (2), 223-238.

Farahat ,G. A. and Salama, N.H.H. (2019) Potential impacts of climatic conditions and some sulfates on sugar beet powdery mildew disease incited by Erysiphe betae fungus in the field. Egypt. J. Plant Pro. Res. 7 (2): 52- 73.

Fawe , A. ;. Abou Zaid, M ; Menzies, J.G. and Belanger, R.R. (1998). Silicon mediated accumulation of flavonoid phytoalexins in cucumber. Phytopathology, 88:396-401.

Fleming, C.A. and Trevors, J.T.(1989).Copper toxicity and biochemistry in the environment :a review. Water Air Soil Polutt. 44:143-158.

Gembeh,S.V.; Brown,R.L.;Grimm, C. and Cleveland,T.E. (2001) Identification of chemical components of maize kernel pericarp wax associated with resistance to Aspergillus flavus infection and aflatoxin production. J. Agric Food Chem. 49 (10): 4635-4641

Ghazy, N. A., El-Gremi, S. and Belal, E. (2017) Chemical and histological differences of maize (Zea mays L.) responsive to Harpophora maydis infection. Env. Biodiv. Soil Security, 1:191-201.
Graham, R.D. and Webb, M.J.(1991) Micronutrients and disease resistance and tolerance in plants .In Welch, editor Welch RM, (Ed.) Micronutrients in Agriculture Madison, Wise: Soil Sci. Soc. of America: 1991, pp: 329-370.

Guevel ,M.H.; Menzies, J.G. and Belanger, R.R. (2007) Effect of root and foliar application of soluble silicon on powdery mildew control and growth of wheat plants. Euro. of Plant Path.119: 429-436.

Hayasaka ,T .; Fuji , H. and Ishinguro, K. (2008) The role of silicon in preventing appresorial penetration by the rice blast fungus. Phytopathology, 98: 10361044.

Huber, D.M. and Withelm, N.S. (1988) The role of manganese in resistance to plant disease. In: Graham RD, Hannam RJ, Uren NC, (Ed.) ; Manganese in Soil and Plants. Dordrecht, The Netherlands: Kluwer Academic Publishers: 1988. pp: 155-175.

Hu, Q.P. and Xu ,J.G. (2011) Profiles of carotenoids, anthocyanins, phenolics and antioxidant activity of selected color waxy maize grains during maturation. J. Agric. Food Chem. 59: 2026-2033.

Inanaga ,S. and Okasaka, A.(1995) Calcium and silicon binding compounds in cell walls of rice shoots. Soil Sci. Plant Nutr. 41:103-110.

Johal L., Huber D.M., Martyn, R.(2004) Late wilt of maize (maize) pathway analysis : intentional introduction of Cephalosporium maydis - In Pathway Analysis for the Introduction to the U.S. of Plant Pathogen of Economic Importance USDAAPHIS Technical Report Nop.503025.

Kablan, L. ; Lagauche, A. ; Delvaux, B. and Legreve, A. (2012). Silicon reduces black sigatoka development in banana . Plant Disease, 96: 273-278.

Kanto , I.. Miyoshi, A. Ogawa, T.; Meakawa, K. and Amo , M. (2004) Suppressive effect of potassium silicate on powdery mildew of strawberry in hydroponic. J.of Gen. Plant Path. 70: 207-211.

Labib , H.A. ; Abdel- Rahim, M.F; Salem, A. and Abdel-Fattah, A. (1975) A new maize hybrid seed resistance to late wilt disease caused by Cephalosporium maydis . Agric. Res. Rev. 53:1-4.

Lamichhane, J.R, ;Osdaghi, E.; Behlau, F. Kohl , J.; Jones, J.B. and Aubertot, J.N. (2018) Thirteen decades of antimicrobial cooper compounds applied in agriculture. A review Agron. Sustain. Dev. 3 8:28:18pp.

Env. Biodiv. Soil Security Vol. 3 (2019) 
Liang, Y.G.; Sun, W. C. and Si, J. (2005) Effect of foliar and root applied silicon on the enhancement of induced resistance to powdery mildew in Cucumis sativus. Plant Path. 54,678-685.

Locke, J.C. ; Pitchay, D. and Frantz, J. (2004) Effect of nitrogen, potassium and silicon on disease susceptibility of various herbaceous ornamental crop species. Phytopathology, 94: S62.

Locke , J.C.; Omer, M.A. ; Frantz, J. ; Widrig , A.K.; Zellner,W.L.; Leisner, S.M. and. Krause , C.R (2008) Potential for the use of silicon to alleviate disease stresses in floriculture crop production. Phytopathology, 98: S93-94.

Matta, A. and Dimond, A.E. (1963) Symptoms of fusarium wilt in relation to quantity of fungus and enzyme activity in tomato stems. Phytopathology, 53: $574-575$.

Nakano, Y. and Asada ,K. (1981) Hydrogen peroxide is scavenged by ascorbate -specific peroxidase in spinach chloroplasts, Plant Cell Physiol. 22: 867880 .

Nanayakkara ,U.N.; Uddin ,W. and Datnoff , L.E. (2008a) Application of silicon sources increases silicon accumulation in perennial ryegrass turf on two soil types. Plant Soil, 303: 83-94.

Nanayakkara ,U.N. ; Uddin ,W. and Datnoff , L.E. (2008b) Effect of soil types, sources of silicon, rate of silicon source on development of gray leaf spot of perennial ryegrass turf. Plant Disease, 92: 870877.

Precigout ,P.A.; Claessen , D. and Robert,C.(2017) Crop fertilization impacts epidemics and optimal latent period of biotrophic fungal pathogens. Phytopathologhy, 107:10:1256-1267.

Reuveni, M. ; Agapov, V. and Reuveni, R. (1997). A foliar spray of micronutrients solutions induces local and systemic protection against powdery mildew (Sphaerotheca fuliginia) in cucumber plants. European J. of Plant Pathol. 103: 581-588.

Rezende ,D.C. ; Rodrigues , F.A. ; Crre-Missio, V. ; Schuri, D.A. ; Kawamura , I.K. and Korndorfer, G.H. (2009) Effect of root and foliar application of silicon on brown spot development in rice. Aust. Plant Pathol. 38:67-73.

Samra,A.S.; Sabet, K.A. and Abdel- Rahim, M.F. (1966) Effect of soil conditions and cultural practices on infection with stalk rots .pp117-164. In Samra,A.S. and Sabet, K.A.(Ed.), Investigations on Stalk - rot Disease of Maize in U.A.R. Min. of Agric.,Gov. Printing Offices, Cairo, Egypt.

Env. Biodiv. Soil Security Vol. 3 (2019)
Seebold ,K.W.; Kucharek ,T.A ; Datnoff, L.E.; Correa -Victoria , F.J. and Marchetti , M.A. (2001) The influence of silicon on components of resistance to blast in susceptible, partially resistant and resistant cultivars of rice. Phytopathology, 91: 63-69.

Shery LeClere; Schmeiz, E.A.and Chourey,P.S,(2007) Phenolic compounds accumulate specifically in maternally- derived tissues of developing maize kernels. Cereal Chem. 84:(4):350-356.

Singh ,S.D. and Siradhana, B.S. (1990) Effect of macro and micronutrients on the development of late wilt of maize induced by Cephalosporium maydis. Summa Phytopathology, 16:140-145.

Singleton, V.L.: Orthofer, R. and Lamuela-Raventos, R.M. (1999) Analysis of total phenols and other oxidation substrates and antioxidants by means of Folin- Ciocalteu reagent. Methods Enzymology, 299: $152-178$.

Soler-Rivas, C. Espi'n, J.C. and Wichers, H.J. (2000) An easy and fast test to compare total free radical scavenger capacity of food stuffs. Phytochemical Analysis, 11, 330-338.

Nuss ET, SA Tanumihardjo (2010) Maize: A Paramount staple crop in the context of global nutrition. Compr. Rev. Food Sci. Food Saf. 9 (4): 417- 436. https:// doi.org/10.1111/j.1541-4337.2010.00117.x

Steel, R.G. and Torrie, J.H. (1980) Principles and Procedures of Statistics, 2nd ed. (pp. 120). McGraw Hill, New York, USA.

Stephenson, G. L., Feisthauer, N. C. and Koper N. et al. (2001) The influence of four types of water on seedling emergence and growth of barley and toxic interaction with copper slufate. In Greenberg BM, Hull RN, Roberts ,MH,Gensemer,RW(Ed.) Environ.Tox.Risk Assess. Sci. Policy, Stand. Environ. Decis. $10^{\text {th }}$ ed. American Soc.for Testing and Materials Min., USA, p.1403.

Verma, J. P., Singh, V. and Yadav, J. (2011) Effect of copper sulphate on seed germination, plant growth and peroxidase activity of mung bean. Int. J Bot. 7: 200-204.

Vidhyasekaran , P. (1988) Physiology of Disease Resistance in Plants, Vol. 11, C RC, Press Florida. p. 128.

Winslow,M.D.(1992) Silicon, disease resistance, and yield of rice genotypes under upland cultural conditions .Crop Sci. 32:1208-1213. 